\title{
Employment and Economic Insecurity: a Commonsian Perspective ${ }^{1}$
}

\author{
SYLVIE MOREL \\ Université Laval, Québec City, Québec, Canada
}

\begin{abstract}
The principal concern of this paper is with the need of a theoretical shift in economics for analyzing and devising efficient and innovative policy reforms to combat employment insecurity. Mainstream economics is unable to provide appropriate theorizing about economic phenomena, including economic insecurity. Thus, we must turn to economic theories which radically question the dominant paradigm in economics. John Rogers Commons's institutionalist theory accomplishes that. First, the author of this paper outlines the distinctive character of this theory by presenting some of its crucial methodological differences with neoclassical economics. Second, she explains how economic insecurity is conceptualized as an "instituted" process with this theory of institution. A better mastery of this specific school of thought in economics appears to escape the problems met by mainstream economics by proposing a real theoretical alternative for the development of a truly evolutionary, trans-disciplinary and ethical economic theory.
\end{abstract}

\section{Introduction}

The inadequacy of mainstream economics, or roughly speaking neoclassical economics, in conceptualizing its own research objects, which are economic realities, is a fact insufficiently known. Indeed, this approach generates an economic analysis on the basis of concepts and models disconnected from the real-world economy. Not surprisingly then, it cannot provide appropriate theorizing about key factors of economic life, nor strategic economic issues. Because of their epistemological posture, neoclassical economists do not pay attention to the real problems of the malfunctioning of economic institutions, and the economic insecurity they generate. Thus, to proceed to a theoretical reconstruction in economics is imperative. What is at stake is our ability to understand economic insecurity in all of its complexity, as well as to conceive creative solutions to it by means of innovative analysis of labour and employment.

If a theoretical shift in economics is a prerequisite to the reorientation of public policies in a progressive way, one must admit that there is not a single alternative to mainstream economics. Indeed, there are several varieties of "heterodox" economic theories, that is to say those questioning the dominant paradigm in economics. 
However, within these theories, priority must be given to the ones focusing on economic security, rights, and duties guaranteeing it. John Rogers Commons's institutionalist theory accomplishes that. Commons is one of the founders of what is called the original institutionalism, which was developed at the end of the $19^{\text {th }}$ century and continued until the 1940s in the United States. Commons's theory, whose relevance to the world today is being rediscovered, provides a coherent interdisciplinary conception of economic facts, grounded in their cultural context, in which economics, law, and ethics are reconciled.

This paper has been divided into two parts. First, we will outline the distinctive character of commonsian institutionalism by presenting some of its crucial methodological differences with neoclassical economics (section 1). Second, we will briefly explain how economic insecurity is conceptualized as an "instituted" process with this theory of institution; note that we will focus on economic insecurity in the area of labour and employment (section 2). To demonstrate that commonsian institutionalism represents a real theoretical alternative to mainstream economics for the development of a truly evolutionary, trans-disciplinary and ethical economic theory is our general concern.

\section{J. R. Commons's Institutionalism: A Radical Methodological Shift from Mainstream Economics}

The theoretical wealth of original institutionalism ${ }^{2}$ is greatly underrated in the field of economics. Indeed, the methodological and conceptual tools of this school of economic thought have been under-utilized in the analysis of the complex realities and major challenges of the $20^{\text {th }}$ century (Adams, 1994, p. 347). ${ }^{3}$ This situation is fully illustrated by the fate that was reserved for J. R. Commons's theory. Indeed, it has been said of him that, within the institutional movement, he was "the least understood of its major theoreticians" (Ramstad, 1986, p. 207). His seminal contributions to the field of labour history and industrial relations have been widely acknowledged (Kaufman, 1998). But, for a long time, Commons's theoretical framework had little impact, despite its strength and originality. ${ }^{4}$ Fortunately, this situation is changing. For example, commonsian institutionalism until recently was generally ignored in France. ${ }^{5}$ However, in recent years, the publication of a number of theses (Bazzoli, 1994; Dutraive, 1993b; Maucourant, 1994; Morel, 1996), books (Bazzoli, 1999; Chavance, 2007; Morel, 2000) and articles, grouped in special issues of journals or published separately in French economic reviews, ${ }^{6}$ has helped to partially fill this gap.

Commons's institutionalism is increasingly being recognized as a fundamental theoretical contribution able to achieve a profound renewal of economic analysis, in all the fields of economics, and particularly, in labour economics and industrial relations (Gislain, 2003b; Ramstad, 1998). In addition, many economists think that commonsian institutionalism can open new opportunities for gender analysis; specifically, many feminist institutionalist economists think that both approaches would benefit to grow by building on one another, as argued by the economists who remain in favour of a "feminist institutionalism" (Jennings, 1993; Mayhew, 1999; Nelson, 2003; Peterson, 1990; Waller \& Jennings, 1990; Whalen \& Whalen, 1994). ${ }^{7}$ 
All this interest comes from the fact that it completely breaks with mainstream economics, insofar as it proposes a logic of inquiry as well as conceptual and methodological tools which are radically different from those of mainstream economics.

First, let us specify why we can speak about a mainstream or orthodox school of thought in economics. Economic theory has developed since the end of $19^{\text {th }}$ century under the label of "neoclassical." This school of thought saw its influence grow gradually during the 20th century to become dominant in the 1940-1950s. Now, for the majority of economists, "economic science" is synonymous with this school. Neoclassical economists adopt a technical definition of economics as being the "science of choice," that is to say "the science which studies human behaviour as a relationship between ends and scarce means which have alternative uses" (Robbins, 1935, p. 16). The coordination of economic activities rests on the "market," an imaginary theoretical construction represented by the confrontation of "supply" and “demand," articulated around a concept of equilibrium (of prices and quantities). Because the market is primarily an intellectual product of economists, a theoretical construct based on a series of assumptions and hypotheses; this sense of the term is to be distinguished from that which refers to the empirical reality of the place where economic transactions occur. Another key element of neoclassical economics is its reference to a perfect competitive model. Society is seen as the collection of autonomous individuals, conceptualized in accordance with the figure of homo øconomicus. Neoclassical economists postulate that economic subjects, or "economic agents," are equal, free, and rational. According to the rationality postulate, economic action is understood as a utilitarian behaviour of utility maximization (or profit maximization) under a budget constraint (or cost constraint). Because of the key role of the rationality postulate and the systematic use of mathematical formalism, in line with the "hard sciences" paradigm, neoclassical economics is defined more by its methodology than by its subject matter.

Of course, neoclassical economics is more complex than what appears here. The basic model has been frequently revised. However, its basic foundations remain the same. For example, if the "economic agent" is studied in "strategic interactions," such as in game theory, its action is still dictated by a utilitarian and optimizing logic; the same observation applies for current labour market theories (such as efficiency wage theory, implicit contract theory, or insider-outsider theory); if modern game theory has stressed "imperfect competition" and "information uncertainty," it is increasingly focused on microeconomic behaviours (the principle of methodological individualism criticized below); if today's mainstream economics seems to some people to integrate the issue of institution, and thus be concerned with institutional issues, its theoretical framework of analysis is still dominated by the concept of the market. From this perspective, the contrast between the orthodox economic current and Commons's heterodox approach is striking. Indeed, while it is beyond the scope of this article to summarize the abundant literature demonstrating the radicality of the departure of the original, or commonsian, institutionalism from mainstream economics, or "new institutional economics" (Dugger, 1996; Dutraive, 1993a; Gislain, 2003a; Gislain, Steiner, 1995; Nelson, 2003; Ramstad, 1986; Tool, 1994), it is crucial to bear in mind that commonsian economics replaces the representation of the economy in terms of the market by one in terms of the institution. Thus, it is fundamentally a theory of institution, ${ }^{8}$ one of its essential 
specific qualities being its articulation with a theory of action (Gislain, 1999); this has nothing to do with the inclusion of "institutional influences" into a theory centred on the market. The same can be said of mainstream economics' purported consideration of "evolution" which is based on methodological principles completely different from the evolutionary conceptions of institutionalist economists like Veblen and Commons (Gislain, 1999) because, in the final analysis, due to its philosophical basis and the methodological choices they entail, commonsian institutionalism is completely extraneous to the basic foundations of mainstream economics. ${ }^{9}$

Indeed, one of the reasons why the theoretical contribution of Commons has not been correctly appreciated until recent years, is that it rests on a philosophical foundation that is not well-known: pragmatism (Bush, 1993; Tool, 1994). As underlined by Y. Ramstad (1998), it "is difficult for most economists to discern the abstract structure of Commons's theoretical system because it manifests heterodox methodological presumptions and because Commons, drawing mainly on Peirce, defended it in the unfamiliar language of American pragmatism” (p. 309). Pragmatism has been qualified as "the first great philosophical movement authentically American” (Deledalle, 1995, p. 24). ${ }^{10}$ Philosophical pragmatism appeared around 1870 in Cambridge, Massachusetts, and received its original shape from Charles Sanders Peirce, William James, and John Dewey. It was influenced by Darwinism, in that both the knowledge and the logic of inquiry cannot be understood in static terms; ${ }^{11}$ they are inherently a process, a process of change, conditioned by the context of inquiry. Commons refers explicitly to Peirce's and, above all, Dewey's "social pragmatism," when talking about the method of investigation he attempts to apply to economics, "the pragmatism of human beings" participating in economic transactions (Commons, 1934/1990, pp. 150, 156, 157). ${ }^{12}$ Thus, the profound originality of commonsian theory stems from the fact that, at the methodological level, pragmatism is radically different from the conception of knowledge inherited from cartesianism, which is the epistemological foundation of orthodox economic theory. To say that original institutionalists use methodological prescriptions, coming from the logic of inquiry of philosophical pragmatism, means that you can contrast neoclassical economists and institutionalist economists on many points, namely the following ones.

First, both schools oppose one another on the conception of objectivity in science. On the one side, neoclassical economists have a dualist conception of the knowledge process: they postulate that the objectivity of the scientific discourse rests on a clear distinction between "positive" (what is) and "normative" (what ought to be) dimensions, pretending that the latter can be excluded from economic science. Economists must study "facts" separately from value judgments which belong to the domain of normative economics. In other words, they defend a view of economic science as a positive science that states universal scientific truths beyond any subjective bias concerning the objects studied. Institutional economists, on the other side, consider that the normative dimension of scientific investigation cannot be extracted in order to produce a purely positive knowledge. Values and judgments are an inescapable part of theory, an inherent and continuing part of the process of inquiry (Tool, 1994, p. 205). Furthermore, for Dewey, "values are a form of knowing." Also, objectivity requires, not an ideal elimination, but the recognition of the importance of values in the reality to be studied at each phase of the process of 
inquiry. ${ }^{13}$ As for Commons (1934/1990, p. 103), he asserts that a pure theory cannot be developed in economics as it can in physical science, "because physical materials have no purposes, wills, rights, or interests." As scientific knowledge is "opinion," in the sense of shared beliefs from those forming the scientific community, the "facts" studied by economists as for example, wages or prices, are not naturally derived from the "free interplay of market laws," but the products of the socially constructed realities of money and value of work. Thus, analysis of economic phenomena is situated in time and space, as they are integrated in their cultural context. The emphasis on culture implies "that social processes are not governed by universal laws and do not have universal meanings; rather, processes and meanings are mutually and historically determined" (Jennings, 1993, p. 114). This also means that the pseudo-neutrality of science, as the aim to which neo-classical theory pretends, is in itself a social construct that must be closely scrutinized in order to identify the hidden ideological content, vested interests, and political agendas it carries.

Second, in the neoclassical theorists' view, an economic problem must be examined by means of deductive reasoning. Thus, inferences regarding all concrete cases are made from an a priori conceived economic model defined with respect to natural law theory. In so doing, neoclassicists pretend to enunciate universal scientific truths. Institutionalists, on the other hand, apply an abductive methodology. For them, knowledge and action are linked. The process of inquiry, in Dewey's terms, is not defined as a purely intellectual operation, but as an action on the world, a transformation of the inquiry subject, a main idea of Dewey's pragmatism. ${ }^{14}$ In social inquiry, theory and facts are in permanent interaction. The instrumental logic of pragmatism rejects essentialism, that is to say "the formulation of eternal verities, first principles, or essences” (Bush, 1993, p. 62). As outlined by Bush, the approach is "contextualist," to the extent that knowledge is developed out of consideration of the context in which facts are an inherent part, instead of being deduced from first principles totally disconnected from the experienced problematic situations inquired. This methodological procedure guarantees a theorization grounded in the reality of economic facts.

Neoclassicists adopt a methodology giving pre-eminence to mathematic formalism, thereby reducing the focus of analytical proposals and constructs to those materials that lend themselves to this treatment. According to a canonical methodological precept of mainstream economics, the validity of a theory rests upon its predictive power, and not its capacity to describe reality. ${ }^{15}$ In contrast, institutionalists regard primarily the capacity of a hypothesis to offer coherence and causal understanding; in that sense, it is not to say that predictability is unimportant but, above all, that predictions do not serve to establish the warrantability of hypotheses (Bush, 1993, p. 75). In fact, institutionalists are especially concerned with "institutional dysfunctions," which cause social problems, such as unemployment, macroinstability, inequality of income, discrimination, environmental deterioration, and the like. They examine how inquiry can contribute to their resolution by remodelling the institutional structure in a progressive way (Tool, 1994, p. 221). The theory is valid if it permits making a useful and creative diagnosis related to the identification and the resolution of real problems. This again relates to pragmatism, which is a "philosophy of the citizen": "The essential task of the American philosopher is to serve society. It is in that sense that we use the word 
'citizen': the citizen is the servant of the city. The philosopher is a citizen" (Deledalle, 1954, p. 187). ${ }^{16}$

The treatment of time is another main difference between the two schools of thought. Mainstream economics is constructed around the notion of general equilibrium (Guerrien, 1989) and, consequently, is static. More importantly, equilibrium implicitly conveys a normative dimension while it depicts a situation of harmony of interest. Indeed, neoclassical equilibrium is optimal, when "we live in the best of all possible worlds, barring minor frictions" (Dugger, 1996, p. 33). In contrast, institutionalists focus on dynamic change and the conflicts of interests which necessarily arise through it. Institutionalism is described as a "processual paradigm" insofar as its subject is economic process, as it takes place in a specific, dynamic, cultural context (Dugger, 1996, p. 31). To explain the process of continuous change, institutionalists use an evolutionary methodology. This term refers to a non-teleological and processual approach differing from the one "evolutionist" economists use in defending the idea of a law of progress (Gislain, 1999). From that perspective, institutions are understood as being in continuous transformation in historic, unpredictable, and irreversible time. Consequently, the researcher must go back to history to be able to grasp reality, especially the genesis of the customs which are crucial in the dynamic process of institutional change.

If we can say that the conception of a logical and fictitious time in neoclassical theory makes it disappear, so does society. Indeed, society is reduced to the aggregation of its parts. In accordance with the principle of methodological individualism, the explanation of economic phenomena rests on the analysis of individual behaviour. Human action is conceived in a very specific manner, that is, as previously stated, according to a theory of action centered on the homo œconomicus postulate. Thus understood, the economic agent is an isolated individual whose actions are motivated by a purely introspective utility maximizing behaviour. For institutionalists, on the one hand, the individual is not examined as an isolated being, but as a social being whose individual action is based on logics that are socially regulated by the working rules ${ }^{17}$ of custom and the going concerns to which his or her social groups belong. This refers directly to Commons's original theory of the institution whose essential characteristic is to be a theory of action (Gislain \& Steiner, 1995; Ramstad, 1993). The institution is defined as "Collective Action in Control of Individual Action” (Commons, 1934/1990, p. 69) expressing the fact that individual action is "embedded" in the broader logic of collective action, not least because of the mere fact of living in society. As shown by Commons (1934/1990, p. 73), if "it be considered that, after all, it is the individual who is important, then the individual with whom we are dealing is the Institutionalized Mind." This is consistent with the whole-part mode of apprehending reality, typical of the holist method endorsed by Commons (Ramstad, 1986). In Commons's words, to speak of a transactional economy, "we can rightly say, regarding the operations of the human will, that the whole is more than the sum of its parts" (1934/1990, p. 629). However, it must be noted that this holist approach does not result in any kind of determinism. Indeed, on the other hand, Commons defends a theory of action that leaves a wide scope for human will. Thus, even if individual action is a social construction regulated by internalized rules in the institutionalized mind, the latter is at the same time an active subject in the process of transforming these rules, since his or her 
action informs their evolution. However, in the act of choosing, it is not introspection which dominates, as Commons points out, but projection in the real environment. In accordance with philosophical pragmatism, the individual is an "acting" being whose willingness is shown in action depending on the "situation" and "opportunities" defined by collective action. ${ }^{18}$ In this way, institutions are social constructs in constant evolution which reproduce themselves under the influence of human will. Thus, Commons's approach reconciles collective "control” and individual will, which are usually viewed as irreducible. Institutionalist methodology goes beyond the sterile opposition of both determinism of methodological individualism and holism.

But, let us come back to the definition of the institution, which is far more complex than it seems at first. As previously stated, Commons defines it as being "Collective Action in Control of Individual Action." But he also presents what he calls a "derived" definition of it, "collective action in restraint, liberation, and expansion on individual action” (Commons, 1934/1990, p. 73). Commons proposes an extensive definition to stress the fact that, as he states, "Collective Action is more than control of individual action:

...it is, by the very act of control, as indicated by the auxiliary verbs, a liberation of individual action from coercion, duress, discrimination, or unfair competition, by means of restraints placed on other individuals. And Collective Action is more than restraint and liberation of individual action - it is expansion of the will of the individual far beyond what he can do by his own puny acts. (Commons, 1934/1990, p. 73)

Finally, in neoclassical theory, economics is depicted as a quasi-exact science, different by nature from other social sciences. The metaphor "hard" is applied to its science as the opposite metaphor "soft" is seldom used to depict the difference. The institutionalist way of thinking economics stresses the fact that it is, in reality, a social science. Economics is characterized by its trans-disciplinary nature, involving an inescapable ethical dimension which stems from the fact that it deals with interactions of human beings among themselves.

\section{The Commonsian Concepts: Economic Insecurity as an Instituted Process}

Economic insecurity, in the common use of the term, refers to the uncertainty and precariousness that affect individuals' access to, and maintenance of, the means of existence. But it goes well beyond the pecuniary dimension. Economic insecurity is also, to a large extent, a problem of confidence in the future. It is not only a question of having a low or irregular income, but also of being uncertain about receiving an income at all (Gagliardo, 1949, p. 8). In Commons's view, this refers to the concept of futurity. All individuals and not merely capitalists (Commons, 1934/1990, p. 618), Commons stated, act in expectation of the future: "man lives in the future but acts in the present” (p. 84). As a purposeful going concern, so does a social institution (p. 619). This theory of the human will in action is even labelled by the author a "science of Futurity." 19 Therefore, economic insecurity or its opposite, economic security, can be explained by stressing the strategic role played by the present expectations of the stability of collective action guaranteeing everybody a share of 
the social output. Here we are led to the concept of citizenship by the issue of the "lien social," i.e. the social cohesion necessary to preserve within the going concern of the society so that it can be maintained in operation, which requires that each of the "shareholders" be assured of the security of expectations concerning the part of social wealth which will be returned to them. In other words, it is through an economic theory of citizenship that commonsian institutionalism helps us to conceive economic insecurity in all its complexity, integrating, among others, the ethical dimension of justice. Basically, this refers to the original representation of the economic subject in commonsian institutionalism. Indeed, instead of examining, like orthodox economists, the action of disembodied, isolated economic agents, the commonsian economist deals with people as "citizen-individuals." In other words, the economic subject is considered an individual, connected with various networks of social relations, and as a citizen endowed with rights and duties. In that perspective, the focus for the researcher is on the evaluation of the economic status instituted for individuals. Citizen-individuals are people with rights and duties, freedoms and vulnerabilities. Economic security, or the institution of working rules permitting economic vulnerability to transform into rights, is precisely what is called in commonsian economics an economic status. Such a study of the economic positions occupied by individuals involves various concepts, such as those of social relation, transaction, negotiational psychology, rights and duties, opportunities, and, as noted futurity. Without attempting to develop each of these innovative concepts, I will nevertheless briefly outline the problem of economic insecurity as an instituted process derived from them.

Our starting point can be Commons's definition of institutional economics, because it places us from the outset in the field of ethics. Let us specify first that this definition goes beyond the notion of social provisioning put forward in institutionalist (Dugger, 1996; Mayhew, 1999; Waller \& Jennings, 1990) and feminist literature (Nelson, 1993, 1996; Power, 2004) as an alternative to the neoclassical definition of economics as the "science of choices." To define economics as the study of "social provisioning" is to emphasize the fact that, basically, economic activity refers to the ways people organize collectively to secure their standard of living (Power, 2004, p. 6): "For institutionalists, and for feminists, economies are society's organizations for provisioning [. . .] Provisioning is the process of trying to assure culturally appropriate levels of food, housing, clothing and care” (Mayhew, 1999, p. 480). Institutionalism has been defined by A. Gruchy as "the science of social provisioning" in order also to sketch out the processual nature of this paradigm (as cited in Dugger, 1996, p. 31). Veblen too "understood the real economy as a social provisioning process," in which he included many of women's domestic activities (Jennings, 1993, p. 113). Finally, J. A. Nelson (1993, p. 32) indicates, from a feminist perspective, that the focus on how to ensure the provisioning of human life meets the requirement of a definition of economy which considers human beings in relation to the world. If we now turn to Commons, we find the following definition:

If the subject-matter of political economy is not only individuals and nature's forces, but is human beings getting their living out of each other by mutual transfers of property rights, then it is to law and ethics that we

Studies in Social Justice, Volume 3, Issue 2, 2009 
look for the critical turning points of this human activity. (Commons, 1934/1990, p. 57)

For Commons, political economy was not a technical issue, as is the case for mainstream economics. It dealt with human activity in its relation, not "of man to nature" and things, which is the standpoint of neoclassical economics, but "between man and man.” The focus then is put on human beings interacting in institutions whose function is to regulate property. These institutions evolve over time and space. This definition carries the interactional, legal, and ethical dimensions of economics. It gives a central role to conflicts of interests and power relations that surround the relations of ownership. Economic insecurity is created by the difficulty faced by individuals in ensuring their survival in the ownership rights system of capitalism. Here, the legal dimension of economics is fundamental. Not only must we conceive economic insecurity as a central concern for economists, but we must also understand that this refers, as does any economic problem, to social realities instituted by the rule of law. According to Commons, economists erred by focusing on the actual exchange or use of economic resources and outputs, and by failing to distinguish between the legal transfers of the rights to a thing and its physical transfers. The strategic element of economic life is legal control rather than physical control. From this viewpoint, economic life can be understood in "processual terms as an ongoing series of legal transfers of property rights” (Ramstad, 1986, p. 234). Rules defining property rights structure production and distributional processes. Therefore "there is nothing 'natural' about the concrete character of those rules and the processes they effectuate” (Ramstad, 1998, p. 311), whether these refer to the market or to any other economic entity. By centering on exchangeability, not of things but of property rights, economic analysis can focus on the evaluation of desirable behaviour in human beings in society which is ethics: "But legal control is not only an economic quantity, it is control of the future behaviour of individuals upon which the dimensions of that economic quantity will depend” (Commons, 1934/1990, p. 87).

But if "the ultimate unit sought in the problem of correlating law, economics, and ethics is a unit of conflicting interest of ownership," this is an incomplete picture of economic interrelations: "the ultimate unit of activity must also be a unit of mutually dependent interests” (Commons, 1934/1990, p. 57). In fact, mutual dependence is, as conflict, another basic fact of economic life. This, in turn, implies the maintenance of order. Order is maintained by the working rules of collective action which govern the transfer of legal control of property rights, but also efficiency through cooperation (Commons, 1934/1990, p. 6). Cooperation is necessary to efficiency and to overcome scarcity, but it does not arise from a presupposed harmony of interests. Cooperation must instead be seen as an "artificial” harmony of interests, coming from the necessity of efficiency and institutionalized through collective action. So, contrary to the principles of orthodox economics, according to Commons, "harmony is not a presupposition of economics-it is a consequence of collective action designed to maintain rules that shall govern the conflicts” (p. 7). These working rules are precisely what ensure security of expectations: "the orderly expectations, assumed by all economists under the name of "security," which is a special case of the general principle of Futurity, we name, for our present purposes, simply Order" (p. 58). 
This brings us to the concept of transaction, that is, for Commons, "the smallest unit of institutional economics" (Commons, 1934/1990, p. 58). The three principles of conflict, dependence, and order are contained in each transaction. (p. 92). Transaction-trans-action-expresses the theoretical shift already mentioned that goes from exchange of commodities to relations between individuals. Transactions are transfers of property rights: "Transactions [...] are not the exchange of commodities, in the physical sense of delivery, they are the alienation and acquisition, between individuals, of the rights of future ownership of physical things, as determined by the collective working rules of society" (Commons, 1934/1990, p. 58). These transfers of rights must be negotiated between the parties concerned, and consequently give place to a negotiational psychology. But, unlike the essentialist, physicalist, and one-dimensional standard analysis, which shows only the homo œconomicus, institutionalism offers a pluralist theory of instituted action (Gislain \& Steiner, 1995). Indeed, rather than a purely fictitious logic of action and applicable to all economic agents in all transactions, it illustrates the diversity of economic positions of actors. This comes from the fact that these positions and the logics of action implemented within them, depend namely on the characteristics of the types of transactions in which the actors are involved. As the commonsian theory of the transaction includes different types of transactions, in each one several types of actors' positions are made possible by their specific working rules.

Thus, transactions resolve themselves into three types: bargaining, managerial, and rationing transactions. ${ }^{20}$ These are the "ultimate units of activity into which all economic relations can be resolved” (Commons, 1934/1990, p. 117). First, the bargaining transaction is the social relation covering the transfers of legal control of property rights and brings together parties, although deemed to be legally equal (as are formally the employer and the worker), "may be economically unequal (coercion) or economically equal (persuasion)" (p. 64) (such as what often happens during labour contract negotiations). Its purpose is the distribution of wealth and the inducement to produce and deliver wealth. This transaction is instituted on the basis of at least five actors (two buyers and two sellers, meaning that there is almost always potential for another buyer or seller in a transaction). The negotiational psychology, or the psychology of action specific to the negotiation carried out in the transaction, by which the transactors mutually influence their conduct, is that of persuasion or coercion. ${ }^{21}$ Ultimately, scarcity is the underlying principle of bargaining transactions.

Secondly, the managerial transaction is the social relation concerning the production of wealth and grows out of a relation between two persons instead of four: a superior and an inferior (such as the supervisor and the worker or the manager and the managed). Command and obedience is the negotiational psychology of managerial transactions and efficiency is its principle (p. 64).

Thirdly, the rationing transaction is the social relation relative to the "negotiations of reaching an agreement among several participants who have authority to apportion the benefits and burdens to members of a joint enterprise" (like the activity of a board of directors of a corporation in making up its budget for the ensuing year, of a legislative body in apportioning taxes, or of collective bargaining between an association of employers and an association of employees) (p. 67-68). Founded on the principle of sovereignty, this transaction constitutes a relation of "authority," in 
which transactors are in a legal position of inequality, from superior to inferior. Its negotiational psychology is that of pleading and argument. For Commons, these three types of transactions are functionally interdependent, so that they together constitute what he calls a going concern, an expression designating all types of social organizations in which the individual member is controlled by the same set of informal (custom) and formal working rules, such as the family, the corporation, the trade union, the State, and so on (p. 70).

In various transactions, individuals can occupy different economic positions that respectively endow them with a set of rights and duties towards other individuals and the collectivity (p. 81). The commonsian conceptualization of the actor's status is thus developed. It is worth noting here that, for Commons, security is primarily an economic concept (Morel, 2003). Indeed, it is one of the four economic statuses derived from social relations. First, for Commons, an economic status is a social relation "consisting of the expectations towards which each party is directing his economic behaviour" (p. 70). The four types of economic status are security, conformity, liberty, and exposure. In Commons's institutionalism, the control of individual action by collective action can create four types of situations: power, disability, immunity, and liability. In accordance with the principle of relations reciprocity, these statuses are instituted in pairs. Commons points out that they correspond, in the field of ethics and law, to social relations, which are conjugated in terms of rights and duties. ${ }^{22}$ To institute an economic status of security-in other words to guarantee a position of "security of expectations" as to the means of existence of each citizen who, otherwise, would be in a position of exposure - means to create rights for those who have a power deficit in social negotiations - the source of their economic insecurity-and working rules to compensate for the effects of their position of economic inferiority. Since the relation between the economic positions held by individuals are correlative and reciprocal, to institute rights for some means to simultaneously institute duties for others. By imposing duties on those who hold, relatively speaking, an excess of power, the rights of others can be protected. In theoretical terms, we can state that if collective action intervenes to support individual action, it creates a right for the individual, which corresponds, for his or her counterpart in the transaction, to a duty. This right/duty pair creates the economic status of security/conformity. The alternative option, where collective action does not provide any guarantee, is a case of non-right, and symmetrically of non-duty. The corresponding economic status is exposure/liberty. This means that one transactor is exposed to gain or loss equivalent to the exercise of liberty by the other, who can do as s/he pleases (p. 81). The identification of each element is relatively easy to the extent that we accept that, in an employment relationship, employers and employees are not in a symmetrical position: employers have a greater power of negotiation, with the option of holding back the product (employment).

Then, we see that, instead of depicting the economy as a mechanism automatically oriented towards equilibrium and peaceful harmony where equal economic subjects meet, commonsian institutionalism focuses on economic inequality and power relationships between individuals and groups, and the reality of conflict in the distribution of income and wealth. The acknowledgment of these key issues is a big step for the understanding of real economic life. In fact, it means that economic analysis goes beyond an individual's status of legal equality and draws attention to 
the different modes of transactional psychology as actually occurs in the negotiations: "The ethical psychology, or what we call negotiational psychology of bargaining transactions is, as we saw above, that of persuasion or coercion, depending on opportunity, competition, and bargaining power" (Commons, 1934/1990, p. 64). Therefore, according to the specific characteristics of each transactional relation and of the law regime concerning the conditions of competition, some situations of abuse of bargaining power and coercion may occur. To analyse economic insecurity as an instituted process means, first, that this reality of unequal bargaining power in the relation of employment is fully taken into account. Second, it signifies that transactors's economic positions are understood as social constructs: as the product of working rules of collective action, they are institutionally generated. Commons viewed the economy as an "authoritatively instituted complex of intertwined working rules” (Ramstad, 1998, p. 311). Thus, economic status reflects the collective willingness or, conversely, lack of willingness, to set up the working rules necessary to compensate for deficits of power within society. In other words, there is no such thing as an unregulated economy. The current situation results, not from an absence of an actor's intervention, but of specific kinds of it: income inequality, low wages, precariousness, reduced social security, and lack of public services, or macroeconomic instability come from collective actions reducing responsibility towards labour of, mainly, employers and the state. This is done by transferring the cost of economic adjustment to labour. In commonsian terms, it reflects the choice to institutionalize positions of non-duty, or economic status of liberty, which permit the development of management practices and state interventions defining non-right positions, or economic status of exposure for large segments of the population.

Commons thought that the insecurity of labour threatened Western civilization. This is why he considered security the major "labor problem" of capitalism (Commons, 1921b). In this context, fostering economic security of the majority was an economic objective at least as important as fostering security for investment (Commons, 1921a). It is not surprising then that he devoted so much effort, not only to theorize economic insecurity, but to combat it also as a practitioner. In accordance with the pragmatist abductive method, throughout his life, Commons developed theoretical analysis in conjunction with its research to solve real problems. This approach to inquiry was therefore systematically followed by the author until he developed his sophisticated theoretical framework: "Commons's theories were themselves continually tested and revised through their applicability to the innumerable concrete problems he wrestled with as a member of both state and federal commissions and as the author of several pieces of innovative legislation" (Ramstad, 1986, p. 209). Commons could therefore feed his theoretical analysis of his long experience as a practitioner in the field of arbitration in industrial relations and social policies (industrial accidents, unemployment insurance, etc.). Speaking of the debates surrounding the draft program of unemployment insurance in Wisconsin, ${ }^{23}$ he said: "It was, indeed, through the aid of these ten-year discussions and my participation in them that I finally reached the formulation of the more abstract theory of "institutional economics" which I now learned to define as collective action in control, liberation, and expansion of individual action" (Commons, 1934/1990, pp. 841-842); the latter is, as we said earlier, the extensive

Studies in Social Justice, Volume 3, Issue 2, 2009 
definition of the institution. Thus, for Commons, the pragmatist theoretician, theory, and practice were two dimensions of the process of social change:

For Commons, theory and practice should go hand in hand. His concern with how to alter economic theory so as to take proper account of the institutional factor and his practical concern with how to bring about a reasonable reconciliation of the conflicting interests of business and labor are simply different aspects of the same problem (Rutherford, 1990, p. xxxii).

It is by virtue of the principle of reasonableness that rules counteracting the effects of the position of economic inferiority of the greatest number should be instituted. It is precisely in these terms, that is to say as working rules compensating economic positions of non-power, that institutions favourable to wage-earners, such as employment policies, labour legislation, and social security programs, should be understood. The concept of reasonable value is the ethical principle used to guide the collective process of conflict resolution to a social order formed in reference to the preferred practices, for a given society and at a given period, that is for a given historical stage of development. ${ }^{24}$ For Commons, the meaning of Reasonable Value, or Reasonable Capitalism, is an attainable ethical ideal: it can be named Pragmatic Idealism in the sense that this "highest attainable regard for one's social responsibilities" is an ethical goal "evidenced by the fact that it actually exists, and can be investigated and testified to as facts, in the practices of the best concerns that are able to survive in the then existing struggle for existence" (Commons, 1934/1990, p. 741). Thus, this is how working rules of collective action can guarantee to "citizen-workers," who otherwise would be in a position of economic exposure, economic positions of security of expectations in relation to the behaviours of actors on which their livelihoods depend. Thus, the citizen to whom we lend a hand in arranging counter-powers that will institute her or him in a position of right, will be empowered of "recognized capacity" to call upon the collective force of the concern to protect and assert for him all the claims against others which the rules of the concern recognize and enforce" (Commons, 1934/1990, p. 688). And this, Commons adds, "is the meaning of Citizenship and Membership." Because he anticipates that authoritative power will be instituted for him or her, the actor may have confidence in the future and, according to the concept of futurity, adapt correspondingly his or her current behaviour. As this confidence in working rules of collective action permits individuals, as well as groups, to go ahead without fear (p. 696), his present action will emerge transformed. ${ }^{25}$ Thus is the meaning of the institution of economic status of security.

Finally, the theory of reasonable value depicts an economic conception of justice. As explained by Y. Ramstad (1998, p. 317), it reflects a theoretical shift in economic theory, "from the practice of viewing allocative efficiency as the overriding economic problem to that of viewing economic justice-the realization of reasonable values — as the paramount problem." As society means "the concerted action of all participants in a going concern," a project of social justice must give importance to the shares of the total output which participants are able to command in order to be considered a part of the concern (Commons, 1934/1990, p. 617). The best nation, stated Commons, (p. 634), is "that where rights, duties, liberties, and exposures are best rationed among individual and classes.” A related point is that reasonable value 
is connected to industrial democracy. In fact, Commons's "citizenship theory of labour" (Ramstad, 1998, p. 317), or "his theoretical demonstration that just labour market outcomes can emerge only if "collective action in control of individual action" in the labour market is effected through working rules jointly determined by the worker "citizens" of enterprises-provides a theoretical rationale for elevating workers to the role of equal partner in determining the working rules that structure bargaining, managerial, and rationing transactions directly affecting workers.” In that view, the strengthening of a tripartite institution, such as the International Labour Organization (ILO), to deal with contemporary labour problems by promoting labour rights and decent work, finds a theoretical legitimization (McIntyre \& Ramstad, 2003).

\section{Conclusion}

Commonsian general theory demonstrates that it is possible to respond to the inadequacy of neoclassical economics without rejecting a theorizing and sophisticated abstract framework analysis. To the contrary, in this article, we attempted to demonstrate that a crucial challenge confronting us now is to bring to the forefront theories which fundamentally question the dominant paradigm in economics. Being radically different in the way to understand economic rules and processes at the ontological, methodological, and conceptual levels, commonsian institutionalism is a theoretical alternative to mainstream economics.

Commons's theory owes its strength to its social investigation approach, its logic of inquiry rooted in philosophical pragmatism, and its original analytical categories which can be used in a highly flexible way. Consistent with its pragmatist mode of inquiry according to which theory and experience cannot be separated, economic theory is enriched by confronting "facts." While the continuity of human experience is understood as a real process to be closely scrutinized, theory is not a fictive abstraction of reality. In contrast, it is directly connected to the real economic problems that disturb the course of the experiment, whether they happen in the life of an individual or in the functioning of the economy. Therefore, economic theory offers useful analytical framework for action, in particular at the political level of transforming the economic world. On the conceptual level, Commons's institutionalism is a rich and dynamic representation of human action in society, operating on the construction of an individual which contrasts sharply with the homo œconomicus of orthodox economics. The individual in Commons's institutionalism is characterized as a social being. He or she has a will that acts on collective action, and on which conversely, the latter has a direct effect. Collective action delimits individual action, both in terms of imagined possibilities and individual room to manoeuvre. This Institutionalized Mind is a being with bounded reason, more reasonable than rational, living in the future, and whose actions largely draw their meaning from customary rules. He or she is a being whose logic is based on negotiational psychology, deriving from its embeddedness in transactions, that is its commitment to different networks of action, or going concerns. Lastly, the commonsian individual is a citizen with rights and duties which evolve according to the changing rules of these going concerns. Economic status, including that of 
security, is defined by social positions of rights and duties, which are socially constructed and governed by formal and informal working rules. All these elements fundamentally confirm an ethical question. They are tools used to imagine the rules of what is reasonable, which serve to establish the economic status of security. Therein lies the power of Commons's institutional theory for the analysis of conflicts surrounding income distribution and redistribution, as well as the attendant insecurity and poverty. Given its ethical concerns, commonsian institutionalism converges with analyses that seek to bring out issues of equality and justice, such as feminist theory. The democratization of economic knowledge, aimed at giving people more power on economic decisions that affect them, is another of its ethical dimension.

All this should be kept in mind in a period where every government, party or organization is seeking to devise the means to resolve the economic crisis. We know that the current worldwide crisis reveals the structural problems of finance-led capitalism. This specific capitalist configuration characterizes itself, among others, by an over-developed sophisticated financial sector detrimental to sustained employment, due to the fact that labour has become the main adjustment variable in economic processes. If, as desired by the ILO, this crisis-which has now degenerated in many countries into a crisis of employment, jeopardizing the economic status of important segments of the population and primarily those who are the most vulnerable-is a turning point for the goal of achieving decent work and social justice, it is clear that platforms of action should be rooted in a sound theoretical basis. In this regard, J. R. Commons's institutionalism shows that economic theory still has an important role to play in the social sciences.

\section{Notes}

1 The author thanks the reviewers whose comments have helped improve this article, and the translator, Lise M. Douville.

${ }^{2}$ The founders of American institutionalism are T. Veblen, J. R. Commons, and W. C. Mitchell.

3 “'Only a comparatively small percentage of articles in the Journal of Economic Issues is devoted to presenting research findings about actual institutions and economic behavior. (...) What is lacking is good application of that theory in order to explain how some bit of the economy works, in a manner that is interesting and meaningful, in the policy sense, to a wide audience" (Adams, 1994, p. 347).

4 B. E. Kaufman (1998) also shows that two other scholarly contributions of Commons have been widely neglected: his role as a founding member of the field of law and law and economics, and in the founding and early development of the academic field of personnel/human resource management.

5 In this country, Commons's work remained virtually unknown to economists. Gaëtan Pirou was the only one who introduced Commons in his lectures at the École Pratique des Hautes Études from 1935 to 1938, which have been published as: Les nouveaux courants de la théorie économique aux États-Unis. However, institutionnalist tradition has remained alive in the United States within the Association for Evolutionary Economics (AFEE) (1965) and the Association for Institutional Thought (AFIT) (1979). The main institutionalist publications are the Journal of Economic Issues (1967) and the Journal of Institutional and Theoretical Economics.

6 P. Adair (1991), "L’institutionnalisme américain. Un chapitre clos dans l'histoire de la pensée économique.” Cahiers du GRATICE, 1, mai, p. 1-37; M. Renault (1992) "L'économique institutionnaliste et la philosophie pragmatique: la nature humaine, les totalités et les valeurs.” Economies et Sociétés, série PE Oeconomia, n¹7-8, pp. 171-201; 
Cahiers d'Economie Politique. Histoire de la pensée et théories. Lectures de John R. Commons, n’. 40/41 (2001); Cahiers du Gratice, nº 19 (2000); Economie \& Institutions, $n^{\circ}$ 1 (2002) \& $n^{\circ} 2$ (2003).

7 On this question, see Morel, 2007.

8 The same analysis applies in the case of T. Veblen, whose theory of the institution is intended to replace the old political economy; on this question, see Gislain \& Steiner, (1995).

9 And I have not talked about the hermeticism displayed by mainstream economics relative to feminist economics: despite its abundance, the impact of this literature developed since the early 1990s is absolutely negligible (Ferber \& Nelson, 2003).

10 This translation is mine.

11 Importantly, institutionalist economists use methodological darwinism, which is completely different from social darwinism.

12 On links between Commons’s work and John Dewey’s “pragmatic instrumentalism," see Albert \& Ramstad, 1997; Rutherford, 1983; Tool, 1994.

13 "Thus, values as such are not contaminates of inquiry; instrumentally warranted values are the necessary standards by which choices are made in the process of inquiry” (Bush, 1993, p. 90).

14 As outlined by P. D. Bush (1993, p. 98), the term "instrumentalism" refers to the instrumental function of ideas in the process of inquiry, as their value is not appraised in terms of an approximation to an ultimate truth, but for the capacity they possess for the solution of problems.

${ }^{15}$ It is worth noting that this has also been called "instrumentalism," but in a very different sense than pragmatist instrumentalism. In mainstream economics, instrumentalism only means that a theory is an instrument for prediction; see Friedman, M. (1953). The Methodology of Positive Economics, in M. Friedman (Ed.), Essays in Positive Economics, Chicago, University of Chicago Press, pp. 3-43.

${ }^{16}$ This translation is mine.

${ }^{17}$ Terms in italics refer to Commons's concepts.

${ }^{18}$ Choice involves, in one and each act, three dimensions: "performance, the exertion of physical or economic power in one direction; avoidance, the rejection of the next best alternative performance; and forbearance, the choice of a lower as against a higher degree of power in the actual performance" (Commons, 1934/1990, p. 19).

${ }^{19}$ On Commons's conception of futurity, see Gislain, 2002.

${ }^{20}$ There are also two other kinds of transactions in commonsian institutionalism: strategic and routine transactions. They refer to what Commons calls the limiting and complementary factors, used to depict the "human will in action."

21 Negotiational psychology is a social psychology with fundamental communicational components; on the relationship between American pragmatism, commonsian intitutionnalism and communication, see Albert \& Ramstad, 1997; Albert \& Ramstad, 1999; Renault, 1999; 2007.

${ }^{22}$ Commons points out the fact that his formula of "social relations" is derived from the work of Professor Hohfeld of the Yale Law School: "The "social relations" are derived from Hohfeld's "legal relations," but are enlarged to include economic and moral concerns, as well as the State-his political or legal concern" (Commons, 1934/1990, p. 77).

${ }^{23}$ This program, for which Commons was the main instigator, was the first of its kind in the United States. It served as a model to the American unemployment insurance system, originally introduced in the framework of the Social Security Act of 1935.

24 On Commons's reformist ideal of reasonability, and its ethical dimension, see Bazzoli, 1999.

25 A status is "an expectation within which the individual adjusts his present behaviour" (Commons, 1934/1990, p. 412). 


\section{References}

Adams, J. (1994). Economy as an instituted process: Change, transformation, and progress. Journal of Economic Literature, 28(2), 331-355.

Albert, A., \& Ramstad, Y. (1997). The social psychological underpinnings of Commons' Institutional Economics: The significance of Dewey's Human Nature and Conduct. Journal of Economic Issues, 31, 881-916.

Albert, A., \& Ramstad, Y. (1999). The social psychological underpinnings of Commons's Institutional Economics II: The concordance of G. H. Mead's “social self” and J. R.Commons's “will.” Journal of Economic Issues, 33(4), 1-46.

Bazzoli, L. (1994), Action collective, travail, dynamique du capitalisme: fondements et actualité de l'économie institutionnaliste de J. R. Commons, (Thesis). Université de Lyon II.

Bazzoli, L. (1999). L'économie politique de John R. Commons. Essai sur l'institutionnalisme en sciences sociales. Paris, L'Harmattan.

Bush, P. D. (1993). The methodology of institutional economics: A pragmatic instrumentalist perspective. In M. R. Tool (Ed.), Institutional economics: Theory, method, policy (pp. 59-107). Boston, MA: Kluwer Academic Publishers.

Chavance, B. (2007). L'économie institutionnelle. Paris: La Découverte, Repères.

Commons, J. R. (1921a). Industrial relations. In J. R. Commons (Ed.), Trade unionism and labor problems (pp. 1-16). Boston, MA: Gin and Company.

Commons, J. R. (1921b). Introduction. In J. R. Commons (Ed.), Trade unionism and labor problems (pp. ix-xiii).Boston, MA: Gin and Company.

Commons, J. R. (1990). Institutional economics: Its place in political economy. New Brunswick \& London: Transaction Publishers. (Original work published in 1934)

Deledalle, G. (1954). Histoire de la philosophie américaine. Paris: Presses universitaires de France.

Deledalle, G. (1995). La philosophie peut-elle être américaine? Nationalité et universalité. Paris: Éditions Jacques Grancher.

Dugger, W. (1996). Redefining economics: From market allocation to social provisioning. In C. J. Whalen (Ed.), Political economy for the $21^{\text {st }}$ century: Contemporary views on the trend of economics (pp. 3144). Armonk, NY: M. E. Sharpe.

Dutraive, V. (1993a). La firme entre transaction et contrat: Williamson épigone ou dissident de la pensée institutionnaliste? Revue d'économie politique, 103(1), 83-105.

Dutraive, V. (1993b). Les fondements de l'analyse institutionnaliste de la dynamique du capitalisme (Thesis). Université de Lyon II.

Ferber, M. A. \& Nelson, J. A. (2003). Introduction. In M. A. Ferber \& J. A. Nelson (Eds.), Feminist economics today: Beyond economic man (pp. 1-31). Chicago, IL: The University of Chicago Press.

Gagliardo, D. (1949). American social insurance. New York: Harper \& Brothers.

Gislain, J-J. (1999). Les conceptions évolutionnaires de T. Veblen et J. R. Commons. Économies et Sociétés, 34 (1), 47-65.

Gislain, J-J. (2002). Causalité institutionnelle: la futurité chez J.R. Commons, "La futurité est le principe le plus important de l’économie.” Économie et Institutions, (1), 47-66.

Gislain, J-J. (2003a). L'émergence de la problématique des institutions en économie. Cahiers d'économie politique, (44), 19-50

Gislain, J-J. (2003b). L'institution des relations industrielles: le cadre analytique de J. R. Commons. Économie et institutions, 2, 11-59.

Gislain, J-J., \& Steiner, P. (1995). La sociologie économique 1890-1920. Paris: Presses Universitaires de France.

Guerrien, B. (1989). La théorie néo-classique. Bilan et perspectives du modèle d'équilibre général. Paris: Economica.

Jennings, A. L. (1993). Public or private? Institutional economics and feminism. In M. A. Ferber \& J. A. Nelson (Eds.), Beyond economic man, feminist theory and economics (pp. 111-129). Chicago, IL: The University of Chicago Press.

Kaufman, B. E. (1998). John R. Commons: His Contributions to the Founding and Early Development of the Field of Personnel/HRM. In P. B. Voos (Ed.), Industrial Relations Research Association Series, Proceedings of the Fiftieth Annual Meeting. Madison, WI: IRRA.

Maucourant, J. (1994). La monnaie dans la pensée institutionnaliste (Thesis). Université de Lyon II.

Mayhew, A. (1999). Institutional economics. In J. Peterson \& M. Lewis (Eds.), The Elgar companion to feminist economics (pp. 479-486). Cheltenham, UK: Edward Elgar. 
McIntyre, R., \& Y. Ramstad. (2003). Reasonable value and the International Organization of Labor Rights. Économie et institutions, 2, 83-109.

Morel, S. (1996), Le workfare et l'insertion: une application de la théorie institutionnaliste de John R. Commons (Thesis). Université de Paris I.

Morel, S. (2000). Les logiques de la réciprocité. Paris: Presses Universitaires de France.

Morel, S. (2003). Institutionnalisme commonsien, citoyenneté et "sécurité économique." Économie et Institutions, 2, 106-134.

Morel, S. (2007). Pour une "fertilisation croisée” entre l’institutionnalisme et le féminisme. Nouvelles questions feminists. Perspectives féministes en sciences économiques, 26(2), 12-28.

Nelson, J. A. (1993). The study of choice or the study of social provisioning? Gender and the definition of economics. In M. A. Ferber \& J. A. Nelson (Eds.), Beyond economic man: Feminist theory and economics (pp. 23-36). Chicago, IL: University of Chicago Press.

Nelson, J. A. (1996). Feminism, objectivity, and economics. London: Routledge.

Nelson, J. A. (2003). Confronting the science/value split: Notes on feminist economics, institutionalism, pragmatism and process thought. Cambridge Journal of Economics, 27, 49-64.

Peterson, J. (1990). The challenge of comparable worth: An institutionalist view. Journal of Economic Issues, 24(2), 605-612.

Power, M. (2004). Social provisioning as a starting point for feminist economics. Feminist Economics, 10(3), 3-21.

Ramstad, Y. (1986). A pragmatist's quest for holistic knowledge: The scientific methodology of John R. Commons. In M. R. Tool \& W. J. Samuels (Eds.), The methodology of economic thought (pp. 207245). New Brunswick, NJ: Transaction.

Ramstad, Y. (1993). Institutional economics and the dual labor market theory. In M. R. Tool (Ed.), Institutional economics: Theory, method, policy (pp. 173-232). Boston, MA: Kluwer Academic Publishers.

Ramstad, Y. (1998). Commons's institutional economics: A foundation for the industrial relations field? In P. B. Voos (Ed.), Industrial Relations Research Association Series, Proceedings of the Fiftieth Annual Meeting (pp. 308-319). Madison, WI: IRRA.

Renault, M. (1999). Economie et coordination des comportements: communication et interaction. Revue Européennes des Sciences Sociales, 37(114), 265-292.

Renault, M. (2007). Une approche transactionnelle de l'action et de l'échange: la nature d'une économie partenariale. Revue du Mauss, 30, 138-160.

Robbins, L. (1935). An essay on the nature and significance of economic science ( ${ }^{\text {nd }}$ ed.). London: Macmillan.

Rutherford, M. (1990). Introduction to the Transaction edition. In J. R. Commons, Institutional economics: Its place in political economy (pp. xiii-xxxvii). New Brunswick \& London: Transaction Publishers.

Rutherford, M. (1983). J. R. Commmons's institutional economics, Journal of Economic Issues, 17(3), 721-744.

Tool, M. R. (1994). An institutionalist mode of inquiry: Limitations of orthodoxy. In P. A. Klein (Ed.), The role of economic theory (pp. 197-227). Dordrecht, Netherlands: Kluwer.

Waller, W., \& Jennings, A. L. (1990). On the possibility of a feminist economics: The convergence of institutional and feminist methodology. Journal of Economic Issues, 24(2), 613-622.

Whalen, C., \& Whalen L. (1994). Institutionalism: A useful foundation for feminist economics? In J. Peterson \& D. Brown (Eds.), The economic status of women under capitalism: Institutional economics and feminist theory (pp. 19-34). Aldershot, UK: Edward Elgar. 